Article

\title{
The Effect of Fertilization with Sulphur, Boron, and Amino Acids on the Content of Glucosinolate in Winter Rape Seeds
}

\author{
Marek Gugała ${ }^{1}$, Anna Sikorska ${ }^{2, *}$ and Krystyna Zarzecka ${ }^{1}$ \\ 1 Faculty of Agrobioengineering and Animal Husbandry, University of Natural Sciences and Humanities \\ in Siedlce, ul. Prusa 14, 08-110 Siedlce, Poland; marek.gugala@uph.edu.pl (M.G.); \\ krystyna.zarzecka@uph.edu.pl (K.Z.) \\ 2 Department of Agriculture, Vocational State School of Ignacy Mościcki in Ciechanów, ul. Narutowicza 9, \\ 06-400 Ciechanów, Poland \\ * Correspondence: anna.sikorska@puzim.edu.pl; Tel.: +48-(23)-672-30-75
}

Received: 1 March 2020; Accepted: 3 April 2020; Published: 4 April 2020

\begin{abstract}
The study was carried out in 2016-2019 at the Zawady Agricultural Experimental Station $\left(52^{\circ} 03^{\prime} \mathrm{N}\right.$ and $\left.22^{\circ} 33^{\prime} \mathrm{E}\right)$ belonging to the University of Natural Sciences and Humanities in Siedlce, in Poland. The field experiment was established in a split-plot design with three replicates. The studied factors were: I. Three winter rape morphotypes: population morphotype (Monolit variety); restored morphotype with traditional growth type (PT248 variety); restored morphotype with a semi-dwarf growth type (PX115 variety); II. Types of foliar nutrition: (1) control variant-sprayed with water, without foliar nutrition and amino acids; (2) biostimulant Aminoplant; (3) foliar fertilizer Siarkomag + foliar fertilizer Bormax; (4) foliar fertilizer Siarkomag + foliar fertilizer Bormax + biostimulant Aminoplant. The aim of the study was to determine the effect of foliar application of sulphur, boron, and amino acids on the content of glucosinolates in seeds of three winter rape morphotypes (Monolit, PX115, and PT248). The foliar feeding applied reduced the feed value of winter rape seeds. On treatments $(2,4)$, where only amino acids were used or in addition in combination with sulphur and boron, the increase in glucosinolate concentration (GLS) was the largest. Regardless of the type of foliar fertilization used, the Monolit variety contained the lowest concentration of these compounds. The content of glucosinolates in rapeseeds of the studied cultivars varied during the years of the experiment. Studies have shown that the value of this feature increased with the growth of water stress occurring before harvest.
\end{abstract}

Keywords: harmful sulphur compounds; anti-nutritional substances; foliar fertilization; morphotype; semi-dwarf hybrid; Brassica napus L.

\section{Introduction}

According to Halkier and Gershenzon [1], glucosinolates are secondary plant metabolites found in plants of the Brassicaceae (Cruciferae) and Liliaceae families, synthesized by independent means of the metabolism of basic biosynthetic pathways. The mature rapeseed contains the highest concentrations of alkene glucosinolates: progoitrin, gluconapin, glucobrassicanapine, napoleiferin, and indole glucosinolates: 4-hydroxy glucobrassicin and glucobrassicin. Zukalová and Vašák [2] reported that in the glucosinolate (GLS) plants, the following are synthesized from amino acids: methionine, alanine, valine, leucine, isoleucine (aliphatic GLS), tyrosine, phenylalanine (alkenyl GLS), and tryptophan (indole GLS).

The presence of glucosinolates (GLS) in pomace and rapeseed meal, especially in traditional varieties, limits the use of these post-oil products in animal nutrition and is one of the key criteria in 
the registration and cultivation of doubly improved varieties in the European Union. The content of glucosinolates in seeds of doubly improved winter and spring oilseed rape varieties should not be more than 15 micromoles per gram of dry non-fat matter of seeds.

Many authors [3-6] believe that the demand for rapeseed for sulphur (S) and boron (B) is large and amounts to 20 to $30 \mathrm{~kg} \mathrm{~S} \cdot \mathrm{ha}^{-1}$ [7], while for boron it amounts to 145 to $290 \mathrm{~g} \cdot \mathrm{ha}^{-1}$ [8]. Zhao et al. [9] reported that sulphur and boron are necessary for the synthesis of glucosinolates and sulphur amino acids.

Sulphur is absorbed by the roots in the form of sulphate ion $\mathrm{SO}_{4}{ }^{2-}$ and transported via xyl to the leaves. The sulphate ion is reduced in the leaves mainly to cysteine and/or transformed into methionine or incorporated into proteins [7,10]. According to Wielebski [11], the most important functions of sulphur in a plant result from the presence of this component in sulphur amino acids (cystine, cysteine, and methionine), which participate in the formation of proteins, and are also precursors of other important compounds, such as glucosinolates, glutathione, thiamine (vitamin B1), biotin (vitamin $\mathrm{H}$ ), coenzyme A, lipoic acid, thioredoxins, and sulpholipids. Glucosinolates play an important role in the plant in increasing the resistance of plants to stress caused by environmental factors and protecting against pests and diseases.

The glucosinolate content depends on the genetic factor [12-15], agrotechnical procedures [16-21], and environmental conditions [14,22]. Sikorska et al. [14] showed that the population morphotype is characterized by the lowest concentration of these compounds, while Rajtczak et al. [13] stated that half-dwarf hybrids. Many authors $[19,21,23]$ under the influence of foliar fertilization showed an increase in the GLS content in rapeseed, while Yang et al. [24], Jankowski et al. [18], and Sikorska et al. [14] found a reduction in the concentration of these compounds in rapeseed.

The research hypothesis that biostimulants combined with foliar feeding may affect the glucosinolate content in winter rapeseed was adopted in this study. The aim of the study was to determine the effect of foliar application of sulphur, boron, and amino acids on the content of glucosinolates in seeds of three winter rape morphotypes (Monolit, PX115, and PT248).

\section{Materials and Methods}

\subsection{Arrangement of the Experiment and Research Location}

The study was carried out in 2016-2019 at the Zawady Agricultural Experimental Station ( $52^{\circ} 03^{\prime} \mathrm{N}$ and $22^{\circ} 33^{\prime}$ E) belonging to the University of Natural Sciences and Humanities in Siedlce, in Poland. The field experiment was established in a split-plot design with three replicates. The area of one plot for harvest was $21 \mathrm{~m}^{2}$. The studied factors were: I. three winter rapeseed morphotypes: population morphotype (Monolit variety); restored morphotype with traditional growth type (PT248 variety); restored morphotype with a semi-dwarf growth type (PX115 variety); II. types of foliar feeding: (1) control variant-sprayed with water, without using the foliar feeding and amino acids; (2) biostimulant Aminoplant (amino acids, total nitrogen $(\mathrm{N})$ - at least $8.5 \%$ ): I date-in autumn in the phase of 4-6 leaves (BBCH 14-16), II date-in spring after the vegetation starts (BBCH 28-30), III date-in the phase of flower bud development (budding)-beginning of flowering (BBCH 50-61), at doses of $1.0 \mathrm{dm}^{3} \cdot \mathrm{ha}^{-1}$; (3) foliar fertilizer Siarkomag $\left(5 \% \mathrm{MgO}\right.$, total $\mathrm{SO}_{3}-85 \%$, water-soluble $\left.\mathrm{SO}_{3}-10 \%\right)+$ foliar fertilizer Bormax (B-11\%): I date-in autumn in the phase of $4-6$ leaves $(\mathrm{BBCH}$ 14-16), II date-in spring after the vegetation starts (BBCH 28-30), III date-in the phase of flower bud development (budding) - beginning of flowering (BBCH 50-61), at doses of $2.0 \mathrm{dm}^{3} \cdot \mathrm{ha}^{-1}+$ $0.5 \mathrm{dm}^{3} \cdot \mathrm{ha}^{-1}$; (4) foliar fertilizer Siarkomag + foliar fertilizer Bormax + biostimulant Aminoplant: I date-in autumn in the phase of 4-6 leaves (BBCH 14-16), II date-in spring after the vegetation starts (BBCH 28-30), III date-in the flower bud development (budding) - beginning of flowering (BBCH 50-61), at doses of $2.0 \mathrm{dm}^{3} \cdot \mathrm{ha}^{-1}+0.5 \mathrm{dm}^{3} \cdot \mathrm{ha}^{-1}+1.0 \mathrm{dm}^{3} \cdot \mathrm{ha}^{-1}$. Foliar fertilizers were applied with a plot sprayer with flat string nozzles. There were $300 \mathrm{dm}^{-3}$ of working fluid per hectare; $150-\mathrm{cm}$ wide paths were used between the plots. 
In the first year of research, spring wheat was the forecrop for winter rape, in the second and last year of research-winter triticale. The experiment was carried out on soil classified according to the World Reference Base for Soil Resources (2014) [25] to the Haplic Luvisol group, sanded, belonging to the very good rye soil complex, of the IVa class. In the years of the experiment, the $\mathrm{pH}$ (in $1 \mathrm{~N}$ $\mathrm{KCl}$ ) of the soil was slightly acidic and ranged from 5.68 to 5.75 . The soil was characterized by a low content of available forms of phosphorus (ranging from 75 to $81 \mathrm{mg} \cdot \mathrm{kg}^{-1}$ ) and average bioavailability in potassium (ranging from 199 to $202 \mathrm{mg} \cdot \mathrm{kg}^{-1}$ ), magnesium (ranging from 59 to $63 \mathrm{mg} \cdot \mathrm{kg}^{-1}$ ), boron (ranging from 0.48 to $0.52 \mathrm{mg} \cdot \mathrm{kg}^{-1}$ ), and sulphur (ranging from 5.90 to $6.03 \mathrm{mg} \mathrm{SO}{ }_{4}^{2--} \cdot \mathrm{kg}^{-1}$ ).

After harvesting the forecrop, a set of post-harvest cultivations was made with a stubble cultivator and a string roller, and then two weeks after the first treatment, the ploughing was carried out to a depth of $20 \mathrm{~cm}$ along with the ring roller. In order to prepare the soil for sowing and mixing fertilizers, a combined tilling set was used. Before sowing, phosphorus and potassium fertilization was applied at a rate of $40 \mathrm{~kg} \mathrm{P} \cdot \mathrm{ha}^{-1}$ and $110 \mathrm{~kg} \mathrm{~K} \cdot \mathrm{ha}^{-1}$, and the first rate of nitrogen at $40 \mathrm{~kg} \mathrm{~N} \cdot \mathrm{ha}^{-1}$. Fertilization under oilseed rape was applied in the form of Lubofos at a rate of $600 \mathrm{~kg} \cdot \mathrm{ha}^{-1}$, i.e., $21 \mathrm{~kg} \mathrm{~N} \cdot \mathrm{ha}^{-1}, 26.4 \mathrm{~kg} \mathrm{P} \cdot \mathrm{ha}^{-1}, 92.1 \mathrm{~kg} \mathrm{~K} \cdot \mathrm{ha}^{-1}, 34.8 \mathrm{~kg} \mathrm{~S} \cdot \mathrm{ha}^{-1}$, and $1.2 \mathrm{~kg} \mathrm{~B} \cdot \mathrm{ha}^{-1}$. Fertilization rates were supplemented with $55.9 \mathrm{~kg} \cdot \mathrm{ha}^{-1}$ ammonium nitrate $\left(19 \mathrm{~kg} \mathrm{~N} \cdot \mathrm{ha}^{-1}\right), 29.6 \mathrm{~kg} \cdot \mathrm{ha}^{-1}$ triple superphosphate $\left(13.6 \mathrm{~kg} \mathrm{P} \cdot \mathrm{ha}^{-1}\right)$, and $29 \mathrm{~kg} \cdot \mathrm{ha}^{-1}$ potassium salt $\left(17.9 \mathrm{~kg} \mathrm{~K} \cdot \mathrm{ha}^{-1}\right)$. The second nitrogen rate of $100 \mathrm{~kg} \cdot \mathrm{ha}^{-1}$ was applied in the spring before the start of growth $(\mathrm{BBCH} 28-30)$, using ammonium nitrate at a rate of $255.5 \mathrm{~kg} \cdot \mathrm{ha}^{-1}\left(86.9 \mathrm{~kg} \mathrm{~N} \cdot \mathrm{ha}^{-1}\right)$ and ammonium sulphate at a rate of $62.5 \mathrm{~kg} \cdot \mathrm{ha}^{-1}\left(13.1 \mathrm{~kg} \mathrm{~N} \cdot \mathrm{ha}^{-1}+\right.$ $15 \mathrm{~kg} \mathrm{~S} \cdot \mathrm{ha}^{-1}$ ). The third nitrogen rate of $60 \mathrm{~kg} \cdot \mathrm{ha}^{-1}$ was applied at the beginning of budding (BBCH 50) using ammonium nitrate at a rate of $176.5 \mathrm{~kg} \cdot \mathrm{ha}^{-1}\left(60 \mathrm{~kg} \mathrm{~N} \cdot \mathrm{ha}{ }^{-1}\right)$.

The sowing of winter oilseed rape was performed with a row spacing of $22.5 \mathrm{~cm}$, assuming a density of $60 \mathrm{pcs} \cdot \mathrm{m}^{-2}$. Sowing was carried out at the optimal date recommended for this region (in 2016-August 12, 2017-August 14, and in 2018-August 13).

Chemical protection against weeds, diseases, and pests was used in accordance with the recommendations of good agricultural practice. Rapeseed was harvested in two stages in the first and second decades of July (BBCH 89). Four seed samples for each variety were taken for chemical analysis.

\subsection{Chemical Analysis of Seeds}

The content of glucosinolates were performed at the chemical and technological laboratory of the Cultivar Testing Experimental Station at Słupia Wielka. The content of glucosinolates $\left(\mu \mathrm{M} \cdot \mathrm{g}^{-1}\right)$ in the dry matter of seeds was determined using high pressure liquid chromatography (HPLC), using columns with reversed phases and gradient elution according to PN-EN ISO 9167-1:2019 [26]. The method of determination is based on the extraction of glucosinolates with methanol, followed by purification and enzymatic desulphation on ion exchange resin. The determination is carried out on a high-pressure liquid chromatograph (HPLC) equipped with an ultraviolet detector, using reversed-phase columns and a gradient elution.

\subsection{Statistical Analysis}

The study results were statistically analyzed by means of the analysis of variance. The significance of sources of variation was tested with the Fisher-Snedecor $F$ test, and the significance of differences at the significance level $\alpha=0.05$ between the compared means was assessed using multiple Tukey intervals. Statistical calculations were made on the basis of our own algorithm written in Excel in accordance with the above mathematical model:

$$
y_{i j l}=m+a_{i}+g_{j}+e_{i j}^{(1)}+b_{1}+a_{i l}+e_{i j l}^{(2)}
$$

$\mathrm{y}_{\mathrm{ij} 1}$-value of the examined feature,

$\mathrm{m}$-population average

$a_{i}$ - the effect of the $\mathrm{i}$-th level of factor A (cultivar), 
$\mathrm{g}_{\mathrm{j}}$ - the effect of the $\mathrm{j}$-th repetition,

$e_{i j}^{(1)}$-error 1 due to interaction of factor A and repetitions

$b_{1}$-the effect of the l-th level of factor B (types of foliar feeding)

$\mathrm{ab}_{\mathrm{il}}$ - the effect of interaction of factor A and B

$e_{i j l}^{(2)}$-random error

\subsection{Weather Conditions}

In the years of the experiment, different weather conditions prevailed (Table 1). In the 2017-2018 growing season, the annual rainfall was $389.2 \mathrm{~mm}$ and was lower by an average of $38.3 \mathrm{~mm}$ compared to the multi-year average. Based on the calculated Sielianinov hydrothermal coefficient, the first and second years of research were optimal. In the 2017-2018 growing season, the annual rainfall was only $13.0 \mathrm{~mm}$ lower compared to the 1996-2010 average, while the average annual temperature was $1.1^{\circ} \mathrm{C}$ higher. In the last year of the study, the annual rainfall was on average $40.8 \%$ lower than the average for many years. The average value of the hydrothermal index was the lowest and amounted to 0.75 . This season had the highest average air temperature and the lowest annual rainfall.

Table 1. Characteristics of climatic conditions in 2016-2019 (Zawady Agricultural Experimental Station, Poland).

\begin{tabular}{|c|c|c|c|c|c|c|c|c|c|c|c|c|c|}
\hline \multirow{2}{*}{ Years } & \multicolumn{13}{|c|}{ Months } \\
\hline & VIII & IX & $x$ & XI & XII & I & II & III & IV & $\mathbf{V}$ & VI & VII & VIII-VII \\
\hline \multicolumn{13}{|c|}{ Precipitation $(\mathrm{mm})$} & Sum \\
\hline 2016-2017 & 31.7 & 13.6 & 69.8 & 19.5 & 22.5 & 0.4 & 15.9 & 25.1 & 59.7 & 49.5 & 57.9 & 23.6 & 389.2 \\
\hline 2017-2018 & 54.7 & 80.6 & 53.0 & 21.3 & 15.8 & 10.1 & 3.2 & 15.4 & 34.5 & 27.3 & 31.5 & 67.1 & 414.5 \\
\hline 2018-2019 & 24.5 & 27.4 & 23.3 & 9.8 & 9.0 & 7.9 & 4.7 & 15.0 & 5.9 & 59.8 & 35.9 & 29.7 & 252.9 \\
\hline $\begin{array}{l}\text { Multiyear mean } \\
\quad(1996-2010)\end{array}$ & 59.9 & 42.3 & 24.2 & 20.2 & 18.6 & 19.0 & 16.0 & 18.3 & 33.6 & 58.3 & 59.6 & 57.5 & 427.5 \\
\hline \multicolumn{13}{|c|}{ Air temperature $\left({ }^{\circ} \mathrm{C}\right)$} & Mean \\
\hline 2016-2017 & 18.0 & 14.9 & 7.0 & 2.4 & 0.0 & -6.6 & -1.3 & 3.5 & 6.9 & 13.9 & 17.8 & 16.9 & 7.9 \\
\hline 2017-2018 & 18.4 & 13.9 & 9.0 & 4.1 & 2.7 & -0.7 & -4.0 & -0.3 & 13.1 & 17.0 & 18.3 & 20.4 & 9.3 \\
\hline 2018-2019 & 20.6 & 15.9 & 9.6 & 7.9 & 0.3 & -3.0 & 2.2 & 4.8 & 9.8 & 13.3 & 17.9 & 18.5 & 9.8 \\
\hline \multirow[t]{3}{*}{$\begin{array}{l}\text { Multiyear mean } \\
\quad(1996-2010)\end{array}$} & 18.5 & 13.5 & 7.9 & 4.0 & -0.1 & -3.2 & -2.3 & 2.4 & 8.0 & 13.5 & 17.0 & 19.7 & 8.2 \\
\hline & \multicolumn{13}{|c|}{ Sielianinov hydrothermal coefficient * } \\
\hline & VIII & & IX & & $X$ & & III & IV & $\mathbf{V}$ & VI & & VII & Mean \\
\hline $2016-2017$ & 0.61 & & 0.28 & & 3.02 & & 1.79 & 3.19 & 1.52 & 1.06 & & .47 & 1.49 \\
\hline 2017-2018 & 1.00 & & 1.92 & & 2.36 & & 2.97 & 0.99 & 0.59 & 0.61 & & 1.12 & 1.44 \\
\hline 2018-2019 & 0.40 & & 0.7 & & 0.94 & & 1.16 & 0.20 & 1.37 & 0.63 & & 0.56 & 0.75 \\
\hline
\end{tabular}

\section{Results and Discussion}

\subsection{The Content of Glucosinolates Depending on the Type of Foliar Feeding}

Our own research demonstrated that the glucosinolate content (GLS) in the rapeseed dry matter determined the types of foliar nutrition. As a result of applying foliar fertilizers, an increase in the content of harmful sulphur compounds in winter rapeseeds was noted. The application of the Aminoplant biostimulant (2) resulted in the largest increase in the concentration of these compounds by an average of $1.69 \mu \mathrm{M} \cdot \mathrm{g}^{-1}$, compared with the control treatment. After applying foliar fertilization with sulphur and boron in combination with amino acids (4), the value of this feature increased by an average of $1.25 \mu \mathrm{M} / \mathrm{g}$, while the smallest (average of $1.00 \mu \mathrm{M} \cdot \mathrm{g}^{-1}$ ) increase in the GLS concentration was recorded in treatment 3 , where sulphur and boron were used. Jankowski et al. [17], thanks to the effect 
of foliar feeding with boron, observed a significant increase in the content of alkene glucosinolates (progoitrin) and a decrease in indole GLS (4-OH-glucobrassicin), and in later studies of the authors [19], under the influence of autumn macro and micronutrient feeding, an increase in the content of alkenyl and indole glucosinolates in rapeseed seeds was observed.

In turn, Yang et al. [24] showed that boron fertilization has a positive effect on feed quality by reducing the concentration of these compounds in rapeseed. Sikorska et al. [14] after using biostimulants (Tytanit, Asahi, and Silvit) showed a significant reduction in glucosinolate concentration in rapeseed. The authors showed that on a treatment without biostimulants, the concentration of harmful compounds was the highest and averaged to $10.15 \mu \mathrm{M} \cdot \mathrm{g}^{-1}$. In other studies by Jankowski et al. [18], intensified foliar fertilization significantly reduced progoitrin levels by $41 \%$ on average and gluconapin by $46 \%$ on average, while in subsequent studies [19], the foliar fertilizers used increased the content of alkene and indole glucosinolates in the dry matter of seeds. Similarly, Filipek-Mazur et al. [21], after applying fertilizers containing sulphur, while Davoudi et al., [23] after applying selenium, showed an increase in glucosinolate content in rapeseed. Kwiatkowski [28], after applying a combination of foliar fertilizers, i.e., $75 \%$ of the NPK dose and autumn spraying with the urea solution + Plonovit $\mathrm{R}$ and $\mathrm{MgSO}_{4} \cdot \mathrm{H}_{2} \mathrm{O}$, while Nawab et al. [29], after foliar application of ammonium sulphate, noted a reduction in the content of harmful sulphur compounds.

\subsection{The Content of Glucosinolates Depending on the Studied Cultivars}

Jankowski et al. [16] reported that the content of glucosinolates in winter rapeseed seeds ranges, on average, from $440-490 \mathrm{~g} \cdot \mathrm{kg}^{-1}(\mathrm{DM})$. The concentration of glucosinolates ranged from 9.79 to $12.27 \mu \mathrm{M} \cdot \mathrm{g}^{-1}$ on average. The lowest glucosinolate content was found in seeds of the Monolit population. It was shown that the concentration of these compounds was higher by $2.48 \mu \mathrm{M} \cdot \mathrm{g}^{-1}$ on average in the seeds of the restored hybrid with traditional growth type (PT248), whereas in the case of the semi-dwarf form (PX115), this value was higher on average by $1.24 \mu \mathrm{M} \cdot \mathrm{g}^{-1}$. Similarly, Sikorska et al., [14] noted the lowest concentration of glucosinolates in the Monolit population form-on average $8.84 \mu \mathrm{M} \cdot \mathrm{g}^{-1}$, while the highest—on average $9.84 \mu \mathrm{M} \cdot \mathrm{g}^{-1}$ was found in seeds of a restored hybrid form with a semi-dwarf growth type (PR 44D06). In turn, Rajtczak et al. [13] showed that the seeds of the semi-dwarf hybrid PR45D03 were characterized by a much lower content of glucosinolates compared to the hybrid with traditional growth type (PR46W31) and the population cultivar (Californium).

Statistical calculations showed the interaction of cultivars with foliar feeding (Table 2), which means that the cultivars tested showed a varied response to foliar fertilization. Under the influence of foliar nutrition, a significant increase in glucosinolate content was observed in the studied morphotypes. In all studied cultivars, the concentration of glucosinolates was the highest after using the biostimulant containing amino acids (Aminoplant), and ranged on average from 10.15 to $13.20 \mu \mathrm{M} \cdot \mathrm{g}^{-1}$, while it was the lowest on treatment 3 , on which sulphur and boron were applied in a foliar manner. Regardless of the type of foliar fertilizers used, the Monolit variety accumulated significantly less of these compounds than heterosis varieties (PT248 and PX115).

Based on our own research, it has been shown that years interact with varieties, which means that varieties reacted to changing climatic conditions in different ways in the years of experiment (Table 2). In all the years of research, the Monolit population variety was characterized by the lowest concentration of glucosinolates, while the value of this trait was the same in the last two years of research, while the largest was the restored hybrid with traditional growth type (PT248). In the growing season of 2018-2019, the highest content of harmful sulphur compounds in the seeds of all studied varieties was recorded. 
Table 2. Glucosinolate content $\left(\mu \mathrm{M} \cdot \mathrm{g}^{-1}\right)$ depending on the factors of the experiment.

\begin{tabular}{|c|c|c|c|c|c|c|c|c|}
\hline \multirow{4}{*}{ Cultivars } & \multirow{3}{*}{\multicolumn{3}{|c|}{ Years }} & \multicolumn{4}{|c|}{ TYPES OF FOLIAR FEEDING } & \multirow{4}{*}{ Mean } \\
\hline & & & & \multicolumn{4}{|c|}{ TREATMENTS } & \\
\hline & & & & 1. & 2. & 3. & 4. & \\
\hline & 2016-2017 & 2017-2018 & 2018-2019 & $\begin{array}{l}\text { Control } \\
\text { Variant }\end{array}$ & $\begin{array}{l}\text { Biostimulator } \\
\text { Aminoplant }\end{array}$ & $\begin{array}{l}\text { Foliar Fertilizer } \\
\text { Siarkomag + Foliar } \\
\text { Fertilizer Bormax }\end{array}$ & $\begin{array}{c}\text { Foliar Fertilizer Siarkomag }+ \\
\text { Foliar Fertilizer Bormax }+ \\
\text { Biostimulator Aminoplant }\end{array}$ & \\
\hline Monolit & $9.65^{\mathrm{a}}$ & $9.81^{\mathrm{c}}$ & $9.91^{\mathrm{c}}$ & $9.30^{\mathrm{a}}$ & $10.15^{c}$ & $9.77^{f}$ & $9.94^{\mathrm{f}}$ & $9.79^{a}$ \\
\hline PT 248 & $10.06^{\mathrm{b}}$ & $12.93^{\mathrm{d}}$ & $13.82^{\mathrm{e}}$ & $10.50^{\mathrm{b}}$ & $13.20^{\mathrm{d}}$ & $12.51^{\mathrm{g}}$ & $12.86^{\mathrm{i}}$ & $12.27^{b}$ \\
\hline PX 115 & $9.82^{\mathrm{c}}$ & $11.17^{\mathrm{e}}$ & $12.08^{f}$ & $10.34^{\mathrm{b}}$ & $11.84^{\mathrm{e}}$ & $10.84^{\mathrm{h}}$ & $11.09^{j}$ & $11.03^{c}$ \\
\hline Mean & $9.84^{a}$ & $11.30^{\mathrm{b}}$ & $11.94^{c}$ & $10.04^{a}$ & $11.73^{b}$ & $11.04^{c}$ & $11.29^{d}$ & - \\
\hline
\end{tabular}

values marked with the same letter do not differ significantly at $\alpha=0.05$. 


\subsection{The Content of Glucosinolates Depending on the Climatic Conditions in the Research Years}

The lowest glucosinolate concentration was found in the first year of the study with the lowest average air temperature and annual rainfall of $389.2 \mathrm{~mm}$, and the highest in the driest and warm growing season of 2018-2019. The results of our own research indicate that a significantly lower amount of rainfall in April, compared with the average of many years in the last year of the study, could have affected the increase in glucosinolate content. Many authors came to similar conclusions [13,30-34], and stated that drought during flowering may affect the concentration of glucosinolate in rapeseed.

Statistical calculations showed the interaction of years with types of foliar nutrition, which indicates a different effect of foliar fertilizers in changing climate conditions during the studies (Table 3). In all the years of research, the highest concentration of these compounds was recorded after the use of the Aminoplant biostimulant, while in the 2016-2017 growing season, the concentration of glucosinolates on the treatment with the Aminoplant biostimulant (2) and after the application of foliar fertilization with sulphur and boron in combination with amino acids (4) was the same.

Table 3. Glucosinolate content $\left(\mu \mathrm{M} \cdot \mathrm{g}^{-1}\right)$ depending on the years and types of foliar feeding.

\begin{tabular}{|c|c|c|c|c|c|}
\hline \multirow{4}{*}{ Years } & \multicolumn{4}{|c|}{ TYPES OF FOLIAR FEEDING } & \multirow{4}{*}{ Mean } \\
\hline & \multicolumn{4}{|c|}{ TREATMENTS } & \\
\hline & 1. & 2. & 3. & 4. & \\
\hline & $\begin{array}{l}\text { Control } \\
\text { Variant }\end{array}$ & $\begin{array}{c}\text { Biostimulator } \\
\text { Aminoplant }\end{array}$ & $\begin{array}{c}\text { Foliar Fertilizer } \\
\text { Siarkomag + Foliar } \\
\text { Fertilizer Bormax }\end{array}$ & $\begin{array}{c}\text { Foliar Fertilizer Siarkomag } \\
\text { + Foliar Fertilizer Bormax + } \\
\text { Biostimulator Aminoplant }\end{array}$ & \\
\hline $2016-2017$ & $9.20^{a}$ & $10.23^{b}$ & $9.84^{\mathrm{f}}$ & $10.09^{b}$ & 9.84 \\
\hline 2017-2018 & $10.24^{b}$ & $11.99 \mathrm{~d}$ & $11.40^{\mathrm{g}}$ & $11.58^{h}$ & 11.30 \\
\hline 2018-2019 & $10.69^{c}$ & $12.97^{\mathrm{e}}$ & $11.88^{\mathrm{d}}$ & $12.21^{\mathrm{i}}$ & 11.94 \\
\hline Mean & 10.04 & 11.73 & 11.04 & 11.29 & \\
\hline
\end{tabular}

\section{Conclusions}

The foliar feeding applied reduced the feed value of winter rape seeds. On treatments $(2,4)$, where only amino acids were used or additionally in combination with sulphur and boron, the increase in the GLS concentration was the largest. Regardless of the type of foliar fertilization used, the Monolit variety contained the lowest concentration of these compounds. The content of glucosinolates in winter rape seeds increased with increasing water stress occurring before the harvest.

Author Contributions: Methodology, K.Z. and M.G.; Software, M.G.; Writing-original draft preparation, A.S.; Review and editing-A.S. All authors have read and agreed to the published version of the manuscript.

Funding: The results of the research carried out under the research theme No. 32/20/B were financed from the science grant granted by the Ministry of Science and Higher Education.

Conflicts of Interest: The authors declare no conflict of interest.

\section{References}

1. Halkier, B.A.; Gershenzon, J. Biology and biochemistry of glucosinolates. Annu. Rev. Plant Biol. 2006, 57, 303-333. [CrossRef]

2. Zukalová, H.; Vašák, J. The role and effects of glucosinolates of Brassica species-A review. Plant Soil Environ. 2002, 48, 175-180. [CrossRef]

3. Asad, A.; Blamey, F.P.C.; Edwards, D.G. Dry matter production and boron concentrations of vegetative and reproductive tissues of canola and sunflower plants grown in nutrient solution. Plant Soil. 2002, 243, $243-252$. [CrossRef]

4. Walker, K.C.; Booth, E.J. Sulphur Nutrition and Oilseed Quality. In Sulphur in Plants; Abrol, Y.P., Ahmad, A., Eds.; Springer: Dordrecht, The Netherlands, 2003; ISBN 978-94-017-0289-8. [CrossRef] 
5. Ahmad, W.; Zia, M.H.; Malhi, S.S.; Niaz, A.; Saifullah, N. Boron Deficiency in Soils and Crops: A Review; IntechOpen: London, UK, 2012.

6. Sienkiewicz-Cholewa, U.; Kieloch, R. Effect of sulphur and micronutrients fertilization on yield and fat content in winter rape seeds (Brassica napus L.). Plant Soil Environ. 2015, 61, 164-170. [CrossRef]

7. Girondé, A.; Dubousset, L.; Trouverie, J.; Etienne, P.; Avice, J.C. The impact of sulfate restrictionon seed yield and quality of winter oil seed rape depends on the ability to remobilize sulfate from vegetative tissues to reproductive organs. Front. Plant Sci. 2014, 5, 695. [CrossRef] [PubMed]

8. Bowszys, T. Działanie Boru w Nawożeniu Rzepaku Ozimego (Brassica napus L.) i Szarłatu Uprawnego (Amaranthus cruentus L.). Ph.D. Thesis, University Publisher University Warmia and Mazury in Olsztyn, Olsztyn, Poland, 2001; pp. 1-75. (In Polish).

9. Zhao, F.; Evans, E.J.; Bilsborrow, P.E.; Syers, J.K. Influence of sulphur and nitrogen on seed yield and quality of low glucosinolate oilseed rape (Brassica napus L.). J. Sci. Food. Agric. 1993, 63, 29-37. [CrossRef]

10. Takahashi, H.; Buchner, P.; Yoshimoto, N.; Hawkesford, M.J.; Shiu, S.H. Evolutionary relationships and functional diversity of plant sulfate transporters. Front. Plant Sci. 2011, 2, 119. [CrossRef] [PubMed]

11. Wielebski, F. The role of sulphur as a factor affecting quantity and quality of yield of winter oilseed rape. Rośliny Oleiste Oilseed Crops 2015, 36, 39-59.

12. Przybylski, R. Canola/rapeseed oil. In Vegetable Oils in Food Technology: Composition, Properties and Uses; Gunstone, F.D., Ed.; Blackwell Publishing: Oxford, UK, 2011; pp. 107-136.

13. Ratajczak, K.; Sulewska, H.; Szymańska, G. New winter oilseed rape varieties-Seed quality and morphological traits depending on sowing date and rate. Plant Prod. Sci. 2017, 20, 262-272. [CrossRef]

14. Sikorska, A.; Gugała, M.; Zarzecka, K.; Kapela, K. The effect of biostimulants on the glucosinolate content in winter oilseed rape (Brassica napus L.) seeds. Plant Soil Environ. 2018, 64, 7-12. [CrossRef]

15. Wenda-Piesik, A.; Hoppe, S. Evaluation of hybrid and population cultivars on standard and high-input technology in winter oilseed rape. Acta Agric. Scand. Sect. B Soil Plant Sci. 2018, 68, 678-689. [CrossRef]

16. Jankowski, K.J.; Budzyński, W.S.; Kijewski, Ł.; Zając, T. Biomass quality of Brassica oilseed crops in response to sulphur fertilization. Agron. J. 2015, 107, 1377-1391. [CrossRef]

17. Jankowski, K.J.; Sokólski, M.; Dubis, B.; Krzebietke, S.; Żarczyński, P.; Hulanicki, P.; Hulanicki, P.S. Yield and quality of winter oilseed rape (Brassica napus L.) seeds in response to foliar application of boron. Agric. Food Sci. 2016, 25, 164-176. [CrossRef]

18. Jankowski, K.J.; Hulanicki, P.S.; Krzebietke, S.; Żarczyński, P.; Hulanicki, P.; Sokólski, M. Yield and quality of winter oilseed rape in response to different systems of foliar fertilization. J. Elem. 2016, 4, 1017-1027. [CrossRef]

19. Jankowski, K.J.; Sokólski, M.; Szatkowski, A. The Effect of Autumn Foliar Fertilization on the Yield and Quality of Winter Oilseed Rape Seeds. Agronomy 2019, 9, 849. [CrossRef]

20. Kováčik, P.; Šimanský, V.; Wierzbowska, J.; Renčo, M. Impact of foliar application of biostimulator Mg-Tytanit on the formation of winter oilseed rape phytomass and titanium content. J. Elem. 2016, 21, 1235-1251.

21. Filipek-Mazur, B.; Tabak, M.; Gorczyca, O.; Lisowska, A. Effect of sulfur-containing fertilizers on the quantity and quality of spring oilseed rape and winter wheat yield. J. Elem. 2019, 24, 1383-1394.

22. Varga, L.; Ložek, O.; Ducsay, L.; Kováčik, P.; Lošák, T.; Hlušek, J. Effect of topdressing with nitrogen and boron on the yield and quality of rapeseed. Acta Universitatis Agriculturae et Silviculturae Mendelianae Brunensis 2014, 58, 391-398. [CrossRef]

23. Davoudi, A.; Mirshekari, B.; Shiranirad, A.; Farahvash, F.; Rashidi, V. Effect of selenium foliar application on oil yield, fatty acid composition and glucosinolate content of rapeseed cultivars under late-season thermal stress. OCL 2019, 26, 43. [CrossRef]

24. Yang, M.; Shi, L.; Xu, F.-S.; Lu, J.W.; Wang, Y.H. Effects of B, Mo, Zn, and their interactions on seed yield of rapeseed (Brassica napus L.). Pedosphere 2009, 19, 53-59. [CrossRef]

25. World Reference Base for Soil Resources. International soil classification system for naming soils and creating legends for soil. In World Soil Resources Reports 106; Field Experiment; Food and Agriculture Organization: Rome, Italy, 2014.

26. PN-EN ISO 9167-1:2019, Rapeseed and rapeseed meal - Determination of glucosinolate content - Method using high performance liquid chromatography. Poland, 2009.

27. Skowera, B. Changes of hydrothermal conditions in the Polish area (1971-2010). Fragm. Agron. 2014, 31, 74-87. (In Polish) 
28. Kwiatkowski, C.A. Response of winter rape (Brassica napus L. ssp. oleifera Metzg., Sinsk) to foliar fertilization and different seeding rates. Acta Agrobot. 2012, 65, 161-169. (In Polish) [CrossRef]

29. Nawab, A.; Anjum, M.M.; Afridi, M.Z. Effect of Ammonium Sulphate Foliar Spray on Grain Yield and Yield Quality of Canola. Austin Food Sci. 2016, 1, 1026.

30. Hu, L.; Cheng, H.; Zhou, G.; Fu, T. Effect of Different Nitrogen Nutrition on the Quality of Rapeseed (Brassica napus L.) Stressed by Drought. In Proceedings of the 12th International Rapeseed Congress Proceedings, Wuhan, China, 26-30 March 2007.

31. Wielebski, F. Response of different types of winter oilseed rape varieties to crop production systems II. Quality of seeds yield. Rośliny Oleiste Oilseed Crops 2009, 1, 91-101. (In Polish)

32. Wielebski, F. The effect of sulphur fertilization on chemical composition of seeds of different breeding forms of winter oilseed rape in the conditions of diverse nitrogen rate. Rośliny Oleiste Oilseed Crops 2011, 1, 75-95. (In Polish)

33. Ullah, F.; Bano, A.; Nosheen, A. Effects of plant growth regulators on growth and oil quality of canola (Brassica napus L.) under drought stress. J. Bot. 2012, 44, 1873-1880.

34. Lääniste, P.; Eremeev, V.; Mäeorg, E.; Jõudu, J. Effect of sowing date on oil, protein and glucosinolate concentration of winter oilseed rape (Brassica napus L.). Agron. Res. 2016, 14, 1384-1395.

(C) 2020 by the authors. Licensee MDPI, Basel, Switzerland. This article is an open access article distributed under the terms and conditions of the Creative Commons Attribution (CC BY) license (http://creativecommons.org/licenses/by/4.0/). 